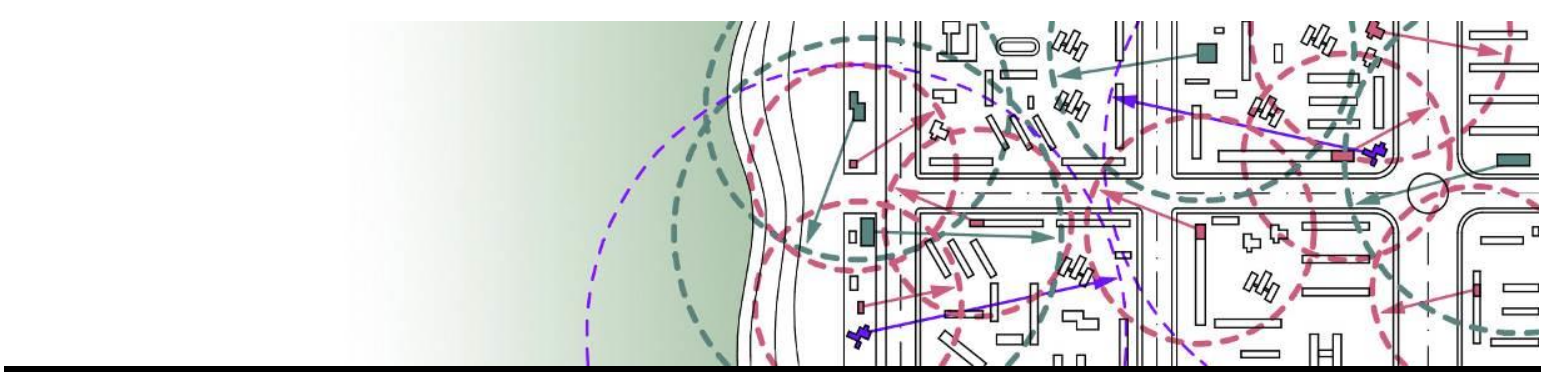

DOI: 10.21005/pif.2021.48.C-08

\title{
REVIEW AND REASSESSMENT THE RADIUS OF PEDESTRIAN ACCESSIBILITY TO CATERING ESTABLISHMENTS
}

\section{PRZEGLĄD I PONOWNA OCENA PROMIENIA DOSTĘPNOŚCI PIESZYCH DO ZAKŁADÓW GASTRONOMICZNYCH}

\author{
Arsenii Troshkin \\ postgraduate student / architect \\ Author's Orcid number: 0000-0001-7394-0923 \\ The National Academy of Fine Arts and Architecture, Kyiv, Ukraine \\ Department of Theory, History of Architecture and Synthesis of Arts
}

\begin{abstract}
This article deals with the issues regarding the accommodation of catering establishments in a residential area and to ensure pedestrian accessibility to them to save time and reduce the load on the city's transport system. It is based on a three-stage service system and the average walking speed of the economically active population. To solve the unsatisfactory location of catering establishments in a residential area, a formula for calculating the service radius for each type of catering establishment, and classify catering establishments into fast, leisure, and mixed types are proposed. To conclude, with the implementation of the attached calculations in urban planning, the location of types of catering establishments in the residential area could solve the set goals.
\end{abstract}

Keywords: catering establishment, walking speed, fast food facility, leisure food facility, exotic location, exotic type, radius.

\section{ABSTRAKT}

W artykule omówiono zagadnienia związane z zakwaterowaniem placówek gastronomicznych na obszarze mieszkalnym oraz zapewnieniem do nich dostępu dla pieszych w celu zaoszczędzenia czasu i odciążenia systemu transportowego miasta. Badanie to opiera się na trzystopniowym systemie obsługi i średniej prędkości chodzenia ludności aktywnej zawodowo. Aby rozwiązać niezadowalającą lokalizację placówek gastronomicznych w dzielnicy mieszkalnej, proponuje się formułę obliczania promienia obsługi dla każdego rodzaju placówki gastronomicznej oraz klasyfikację placówek gastronomicznych na typy szybkie, rekreacyjne i mieszane. Reasumując, dzięki zastosowaniu załączonych obliczeń w urbanistyce, lokalizacja typów lokali gastronomicznych na obszarze mieszkalnym może rozwiązać założone cele.

Słowa kluczowe: placówka gastronomiczna, prędkość chodzenia, obiekt fast food, obiekt gastronomiczny rekreacyjny, lokalizacja egzotyczna, typ egzotyczny, promień. 


\section{INTRODUCTION}

How to place catering establishments in the urban planning system? This is a complex issue that concerns not only urban planning but also the fields of sociology, logistics, ergonomics, business, etc. The main task of the author is to develop a model of placement of catering establishments, which should operate in modern and promising conditions. This requires a critical assessment of the standards for the location of these institutions, which in fact have not been questioned and have not changed since the Soviet years. Cities of Ukraine and their residential areas have been designed and implemented for a long time using a three-stage service system. Today, according to the state building norms of Ukraine (hereinafter DBN), the location of catering establishments is still regulated by a three-stage service system. This system also regulates the placement of other cultural and domestic institutions of service by dividing institutions into everyday, periodic, and episodic. According to this method, the more often the population uses a certain type of institution, the closer it should be to housing and the smaller the radius of service. In this case, public catering should provide residents with a 15-minute walk. Today, this condition is often not provided in residential areas of Kyiv. The reason for this is that catering is usually placed en masse in the area of public centers of residential areas for better economic benefits, and walking distance from a house away from the community center takes much longer than stated time: more than going to the nearest store and cooking at home; more than waiting for the delivery of ready meals. The idea of purposefully visiting a public catering object near the community center after spending a conventional 20 minutes on foot in one direction, is replaced by a rational decision to spend a conditional 30 minutes using transport to a public catering object in the city center, where in addition to meeting the physiological need for food, most public catering objects provide an opportunity to get a comprehensive satisfaction of the need for leisure. Thus, the failure to provide residential areas with pedestrian access to various types of catering in the daily burdens the city's transport system to collapse.

So, the location of public catering establishments within pedestrian accessibility has an increased value for large cities and the time of their inhabitants, who must be able to meet most of their needs by staying in their residential area. In this regard, it is clear that catering establishments do not have a common accommodation system that would satisfy pedestrian accessibility and take into account the interests of the owners of public catering establishments. Thus, the existing system of accommodation of catering in accordance with pedestrian accessibility requires critical analysis, rethinking, updating, and innovation.

The author proposes to evaluate the criteria that have an impact on the location and calculation of service radiuses of catering establishments, as well as to determine their dependence on the physiological need for food and the need for leisure. Such criteria are the walking speed of people of different social groups, the capacity of catering establishments, the exoticism of their types and exoticism of their placement in residential development, the availability of ways to meet the need for leisure, a variety of cuisines.

In this study, under the term "catering establishment", we consider a public catering object located in a residential area and focused primarily on the pedestrian accessibility of the consumer. The object is an organizational and structural unit in the field of catering trade, which carries out production and trade activities: produces and (or) prepares, sells, and organizes the consumption of own products and purchased goods, can organize consumer leisure and (or) provide space for short-term labor, and can arrange delivery of meals to the consumer. By short-term work, we mean work with a laptop or papers, business meetings, etc. This catering facility is located in a residential area in a separate capital building or a specially equipped (possibly attached) room of another capital building, including in hotels, shops, supermarkets, etc.

Thus, by types of catering establishments, we mean restaurant, restaurant-bar, cafe, bar, coffee house, coffee bar, cafe-bakery, teashop, pub, fast food restaurant, food court, food hall, food market.

Most of them are familiar to residents of the largest cities, so we consider it necessary to refine the definition of only such types of catering establishments as: 
Fast food restaurant - Self-service establishment, which is dominated by a range of hot and cold dishes of simple cooking, designed for fast customer service. There are specialized snack bars: "Pizzeria", "Burgers", "Sausages", "Pancakes", "Pies", "Shish kebabs", "Dumplings", "Dumplings", etc .

Food court - A complex of fast food establishments that have a common commercial and consumer space and are built into a house of other public and functional purposes (Shopping Center, Shopping and Entertainment Center, Supermarket, etc.). Due to the location in a single volume of the kitchen line, cash register, and seats, a wide range of products of own production and purchased goods are sold (Fig. 1);

Food hall - A complex of catering establishments of mixed types of service, which have a common trade and consumer zone with the organization of various spectacles and entertainment programs with musical accompaniment (Fig. 2);

Food market - A complex of catering establishments of mixed types of service united by a single volume with a supermarket which is functionally separated from the trade and consumer zone where various entertainment and entertainment programs with musical accompaniment are organized (Fig. 3).

It should be noted that this list does not claim to be a new classification of catering establishments.

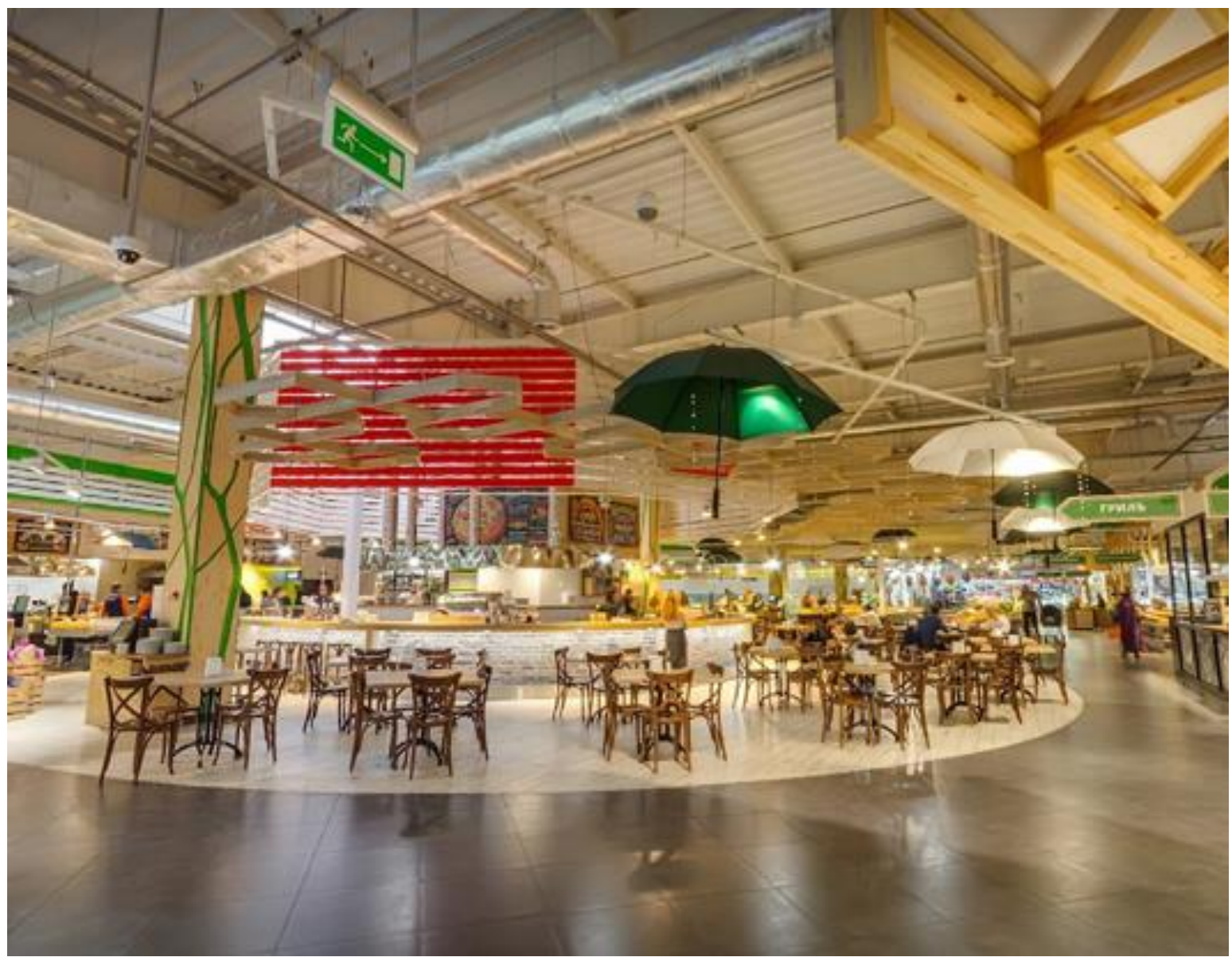

Fig. 1. Food court. Source: Fot. author 


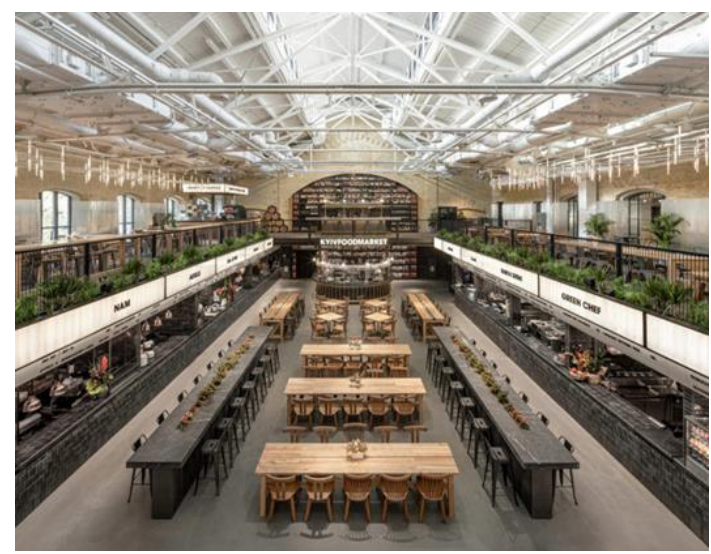

Fig. 2. Food hall. Source: (Hospitalitysnapshots)

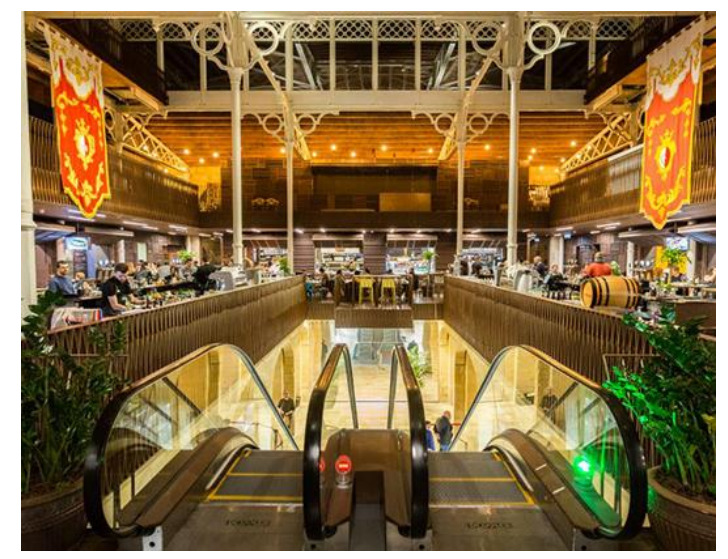

Fig. 3. Food market. Source: (Issuqtalbelt)

\section{STATE OF KNOWLEDGE IN THE FIELD}

Over the last 30 years, a very small number of Ukrainian architects and scientists have dealt with the issue of catering establishments, and the issue of correcting the radiuses of accessibility to public catering establishments has not been raised at all, so these developments are new in Ukraine's urban planning. Among the architects, Nikolaenko V. came closest to the topic in his study "Methods of architectural forming citywide system of public catering" (Nikolaenko V., 2013, p. 160). However, this study covers the entire urban catering system, from the place of cooking in procurement factories to the places where it is shot down, which takes place not only in restaurants and cafes but also in kiosks. Our study differs in that we are interested in the placement of catering facilities from the standpoint of accessibility of the entire typology of catering to the resident of the residential area, and from the standpoint of owners of catering establishments, for who conditions should be created for economic effective placement of catering establishments and fulfilling the condition of pedestrian accessibility to the consumer. Also, we do not agree with the research of Nikolaenko V., that an urban planner can create a system of placement of mobile food facilities and kiosks, according to which they will actually be located, because they are usually located on the streets of the city illegally, such catering facilities we do not take into account.

As the actual situation of accommodation and the number of catering establishments have changed significantly over the years since the establishment of the catering system, and new researches on this issue are not enough, in the state-building norms of Ukraine (DBN, DSTU) in the field of this issue together with their updating there was copying, simplification, or renaming of obsolete norms. According to current state building codes, all catering establishments in multistorey residential buildings have a single service radius of 500 meters from the maximum possible radius of pedestrian accessibility in a residential area of 1,500 meters (DBN B.2.2-12:2019, 2019, p. 21).

In order to understand the scale of simplification of these rules, you should read "System and complexes of cultural and consumer services" (Kulaga V. et al.,1975. p. 85). In this book, an assessment of the effectiveness of the location of catering establishments depending on the type and its radius, also here is a study of the effectiveness of visiting catering establishments with service radiuses from 200 to 800 meters, taking into account the time spent by visitors (Kulaga V. et al.,1975. p. 82). Unfortunately, these indicators cannot be used due to global changes in the world, because in 1975 catering establishments had a smaller typology, a smaller number, were mostly publicly owned, and focused on infrequent visits (Kulaga V. et al.,1975. p. 60). 
Ukraine currently has an outdated classification of catering establishments of 2003, which was updated in 2004 with changes in the name, but without changes in the context (DSTU 3862-99, 2003. pp. 1-26) (DSTU 4281:2004, 2004, p 1-18). The latest state building codes "Establishments of the catering trade" issued in 2010, have the same classification, which has not been supplemented or changed and remains obsolete (DBN V.2.2-25:2009, 2010, p. 177). It is obvious that in 11 years catering establishments have not only increased in number but also a new typology of public catering has emerged. New types of catering establishments, foreign to the Ukrainian practice, were examined in a field survey and described by the author (Troshkin A., 2021, pp. 95-106).

Attention should be paid to the classification of public catering establishments by "average check", developed by E. Yurchak in the dissertation study "Brand management of catering establishments networks" (Yurchak E. 2018. p. 339). according to his research Catering establishments are divided into 7 price segments at the cost of the "average check" (Table 1). Four price segments together occupy $89.69 \%$ of the restaurant market in Kyiv: Fast Food + Fast Casual; Quick Service Restaurant + Quick \& Casual; Casual Dining; Top Casual Dining. It can be argued that the residential area, despite its remoteness from the city center, needs a system of accommodation of food establishments primarily in these price segments. We can also see the division of price segments into fast or quick, casual, and fine service, but the correspondence between the typology of catering establishments and price segments was not found in the study.

Table 1. Distribution of the number of enterprises on the market of the catering trade in Kyiv in 2017. Source: (Yurchak E. 2018. p. 83).

\begin{tabular}{|l|l|l|l|}
\hline $\begin{array}{l}\text { Price segment } \\
\text { at the cost of } \\
\text { the "average } \\
\text { check" }\end{array}$ & Segment name & $\begin{array}{l}\text { Number of operating } \\
\text { catering establishments } \\
\text { in the price category for } \\
\mathbf{2 0 1 7}\end{array}$ & $\begin{array}{l}\text { Percentage of catering } \\
\text { establishments in the } \\
\text { price category, \% }\end{array}$ \\
\hline $2-4$ USD & Fast Food + Fast Casual & 423 & 21,78 \\
\hline $4-10$ USD & Quick Service Restaurant + Quick \& Casual & 946 & 48,71 \\
\hline $10-20$ USD & Casual Dining & 237 & 12,20 \\
\hline $20-30$ USD & Top Casual Dining & 136 & 7,00 \\
\hline $30-40$ USD & Fine Dining Ekstra & 92 & 4,74 \\
\hline $40-50$ USD & Fine Dining Premium & 84 & 4,33 \\
\hline $50-60$ USD & Fine Dining Elit & 24 & 1,24 \\
\hline Total market & & 1942 & 100,0 \\
\hline
\end{tabular}

Thus, we believe that catering establishments require a clear division of the types of catering establishments into those that provide leisure and those that do not provide it but only satisfy the physiological need for food. Since there is reason to hypothesize that such a distribution of the typology of catering establishments will directly affect the system of catering in a residential area, namely the radii of accessibility of catering establishments and the frequency of their placement, which we prove in this study.

In previous studies, the author conducted field and graphical analyzes of residential areas in Kyiv and concluded that in the field of providing residential areas with food, now only developed supermarket chains meet the accessibility of most homes in residential areas, and catering does not cover much of the territory. tories of residential areas by service radii (Troshkin A., 2019, pp. 76-82.). 
According to the results of this study, the placement of the typology of catering establishments in the residential area requires more frequent placement of fast establishments than leisure ones. In this sense, a fast food facility is for daily visits, and a leisure food facility is for periodic.

This study raises the question of the line between rational choices - to visit a catering establishment, or to satisfy the physiological need for food at home, or to order home delivery of food, or to visit a supermarket and cook at home. In our opinion, science needs a more thorough study of the line between these choices, in terms of sociology and psychology, which will further affect urban planning and architecture.

\subsection{Influence of walking speed}

If transport accessibility has changed over the years of technical progress, the walking speed of people since the creation of accessibility radiuses should not have changed. The walking speed of the population is the basis for calculating the accessibility to cultural and domestic institutions of the three-stage service network. The estimated walking speed of the population to determine the radiuses of accessibility in the above regulations - is not specified. A study of the effect of walking speed on accessibility radiuses for different social groups has not been identified. The social groups of the population defined by the architect L. Yaremenko are divided into 5 groups: children of preschool age, children of school age, teenagers and youth, the adult population, the population of retirement age. (Yaremenko L., 2004, p. 41). The calculation of the need in places of establishments of the catering trade takes into account only the economically active population persons aged 15-70 years (ukrstat)(Lytvynenko S., 2009, p. 1). Thus, most catering establishments are aimed at young people, adults, and retirees. This does not contradict the possibility of catering to other socio-demographic groups, but since catering establishments today primarily seek to be profitable, that is why it is necessary to calculate the availability for the economically active population.

Returning to the work of L. Yaremenko, the average walking speed of a person adopted in his study is equal to $4 \mathrm{~km} / \mathrm{h}$ (Yaremenko L., 2004, p. 26). Daily services to the population in the residential area should be provided within 15 minutes on foot (Dipromisto). Accordingly, in 15 minutes the average person will cover a distance of $1 \mathrm{~km}$. The service radius of catering establishments is 500 meters, which is twice less. ( DBN V.2.2-12:2019, 2019, p. 158). We must assume that 15 minutes for walking distance, take into account the time of walking from home to the catering establishment, and back to the house. Also, a walking speed of $4 \mathrm{kph}$ is estimated in the state building codes of Ukraine.

According to the study "Association between walking speed and age in healthy, free-living individuals using mobile accelerometry - A cross-sectional study", the highest average walking speed is people 40-49 years olds, which is $-5.06 \mathrm{kph}$ (Schimpl M, et al., 2011, p. 1). The slowest of the economically active population are people aged 60-69, their average walking speed is 4.66 $\mathrm{kph}$. In 15 minutes on foot, 40-49-year-olds will walk 1265 meters, and 60-69-year-olds will walk 100 meters less -1165 meters. The average walking speed of the economically active population is $4.89 \mathrm{kph}$ (Table 2). Accordingly, the average radius of catering for the economically active population is 611 meters, which is 111 meters, or $122.2 \%$ more than the normative radius (Table 2).

Calculated 111 meters at a speed of $4.89 \mathrm{kph}$ will be covered in 1 minute 21 seconds. The time to get dressed and leave the house is obviously much longer, so hypothetically it can be argued that such a difference is irrelevant for the customer of the catering establishment.

Thus, we obtained a value of $122.2 \%$, which should increase the radius of accessibility for catering establishments in further calculations, which in this study will include both the average walking speed according to regulatory calculations and the average walking speed of economically active people.

It should be noted that in the study of M. Schimpl (2011), the walking speed of 15-19-year-olds is absent. Perhaps this is due to the growth of the human body in this age range, which strongly affects the performance of the study. Hypothetically, it can be assumed that this age category will 
have a walking speed not higher and not lower than the maximum and minimum walking speed of other age groups. Therefore, in our study, we do not take into account this age group.

Table 2. Dependence of radiuses accessibility of the population to public catering establishments on age and speed of walking of people of the economically active population. Source: The main indicators of the table (Greatist), changed and supplemented by the author.

\begin{tabular}{|l|l|l|l|}
\hline Age & Kilometers per hour & Meters per 15 minutes & Radius of access \\
\hline $20-29$ & $4,82-4,89$ & 1214 & 607 \\
\hline $30-39$ & $4,82-5,14$ & 1245 & 622,5 \\
\hline $40-49$ & $4,98-5,14$ & 1265 & 632,5 \\
\hline $50-59$ & $4,66-5,14$ & 1225 & 612,5 \\
\hline $60-69$ & $4,50-4,82$ & 1165 & 582,5 \\
\hline Average age $-44,5$ & Average speed $-4,89 \mathrm{kph}$ & Average distance $-1222 \mathrm{~m}$ & Average radius $-611 \mathrm{~m}$ \\
\hline
\end{tabular}

\subsection{Physiological need for food and need for leisure}

Residents of residential areas, who are not fully provided with public catering, spend more time on a purposeful trip to the catering facility. If the distance is more than the norm and catering is only in the community center, there is every reason to say that a rational solution to meet the physiological need for food, or the need for leisure - to use transport. However, in addition to the cost of transport, three times a day there is a load on the transport system of the city, resulting in additional time spent by the population.

Let us try to confirm the above hypothesis about the appropriate division of the typology of catering into leisure establishments and those that only satisfy the need for food. As a result, catering establishments on the basis of logical arguments will have different radiuses of accessibility.

This hypothesis can be confirmed by following two theoretical situations:

The first situation - purposeful visit to a catering establishment in order to meet the physiological need for nutrition.

The second situation - purposeful visit to a catering establishment in order to meet the needs of food and leisure.

In the first situation, the person will receive quick service and quick satisfaction with the need for food. Such a visit to a catering establishment is most relevant during working hours. Therefore, movement in the residential area has the character of the transition from home to fast food facility and back home. (Fig. 4).

In the second situation, a person consciously agrees to spend more time in a catering establishment, which in addition to food provides leisure. Such a visit, unlike the first group, will take more time and is relevant in free time. Hypothetically, it can be argued that a purposeful visit to a leisure catering establishment will not be intended to return home or work quickly. In this case, pedestrian access to the catering establishment has the character of a transition from home to a restaurant, without a quick return home. Then, walking 15 minutes access to the catering establishment will be equal to a double radius of service - 1222 meters according to the calculations for the economically active population, and 1000 meters according to the normative (Fig. 4). 


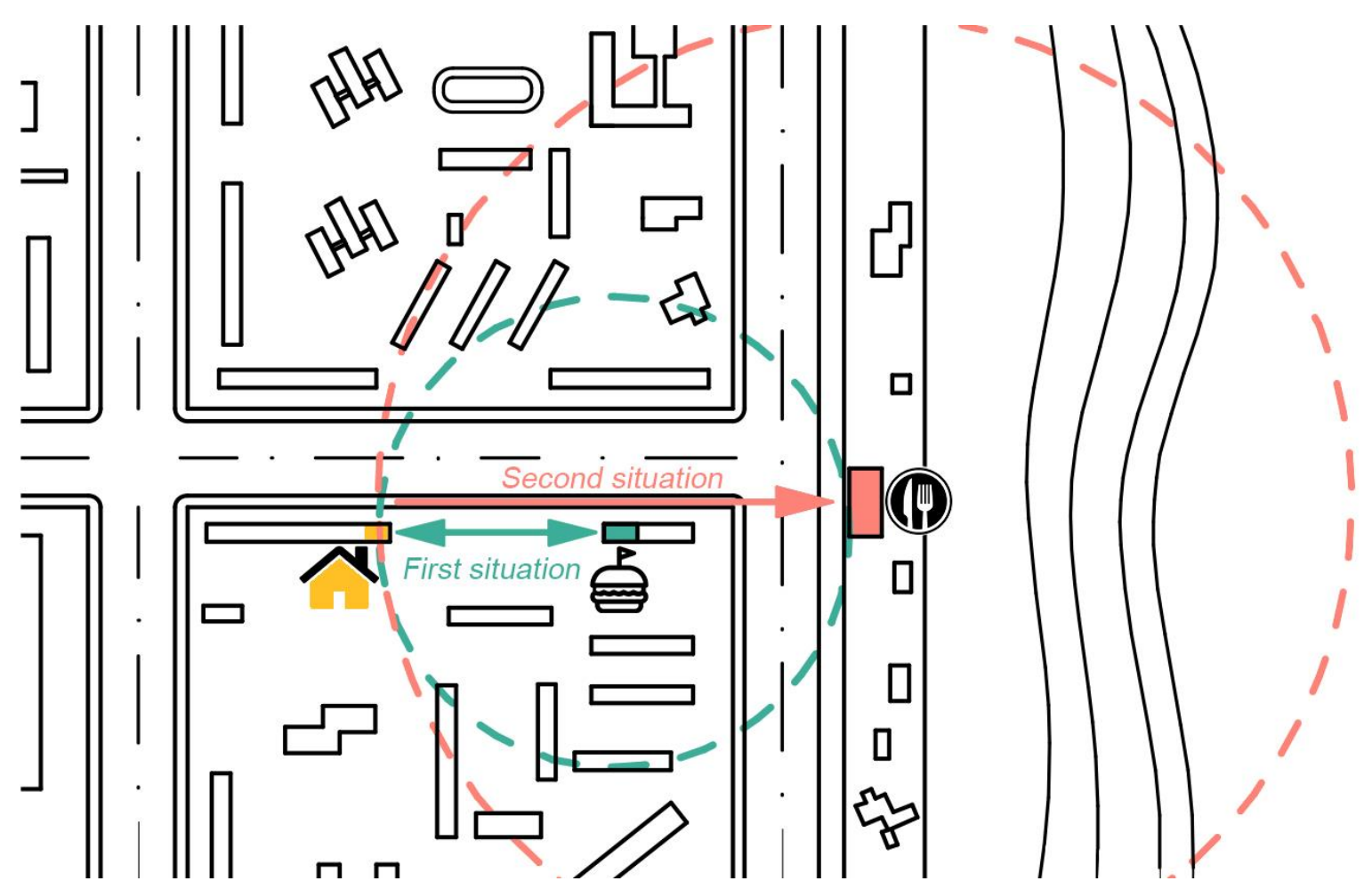

Fig. 4. Two situations of visiting a catering establishment within a 15-minute walk. Source: Author

Evidence that the consumer is willing to spend more time visiting a leisure catering establishment is the fact that leisure catering, in contrast to fast food, provides a comfortable place to wait for an order (up to 40 minutes in an expensive restaurant (UBR)), has a wide range of alcoholic beverages (consumer is unlikely to work on this day), quality of food and price is usually higher, as well as available waiter service, it is possible to leave a tip for service, or they are included in the bill (consumer wants maximum pleasure and best service in relation to the price), the institution organizes additional leisure (music group performance, dancing, billiards), the institution is combined with the function of shopping, library, coworking, etc., and can provide a place of work (business meeting or remote work in the institution via the Internet and laptop, etc.). Obviously, when choosing to visit a particular type of catering establishment, a person considers the appropriateness of this visit, according to the available time, the distance to the catering establishment, the kitchen the consumer wants to taste, the exotic location of the catering establishment, the exoticism or novelty of the type of establishment or its interior solution. Therefore, it is safe to say that there is a subjective line between choosing to visit a catering establishment and eating at home to order, or cooking with the possibility of organizing leisure activities yourself.

\subsection{Calculation of service radiuses}

To calculate the provision of a residential area with catering establishments, there is such a parameter as the capacity of the establishment. The capacity of public catering establishments for a residential area more than 40 years ago was calculated at the stage of designing residential areas when the vast majority of public catering establishments were state-owned. Today, the capacity of a catering establishment is chosen by the owner when calculating the capacity of pedestrian and transport flows and start-up capital, which, in our opinion, confirms that the capacity does not affect the consumer's choice and the radius of accessibility to the catering establishment. When constructing a simple graphic scheme from the standpoint of equal accessibility of a resident of a residential building to catering establishments of different capacities, there is a confidence that 
capacity is not taken into account by the consumer in choosing between catering establishments and their types. The graphic scheme shows the same distance from the house to the restaurant with a capacity of 200 seats and the fast food facility with a capacity of 50 seats, in a situation where these different types of catering have the same service radius as in the DBN (Fig. 5). If you put yourself in the shoes of a resident of the house, it becomes clear that the capacity of the catering establishment is not as important to you as the availability of free time, desire, and finances, which will affect your choice. Therefore, the considered public catering facilities cannot have the same radius due to the presence of these and other criteria considered in the article. Such a conclusion was made based on the graphic scheme and personal experience of living in such conditions.

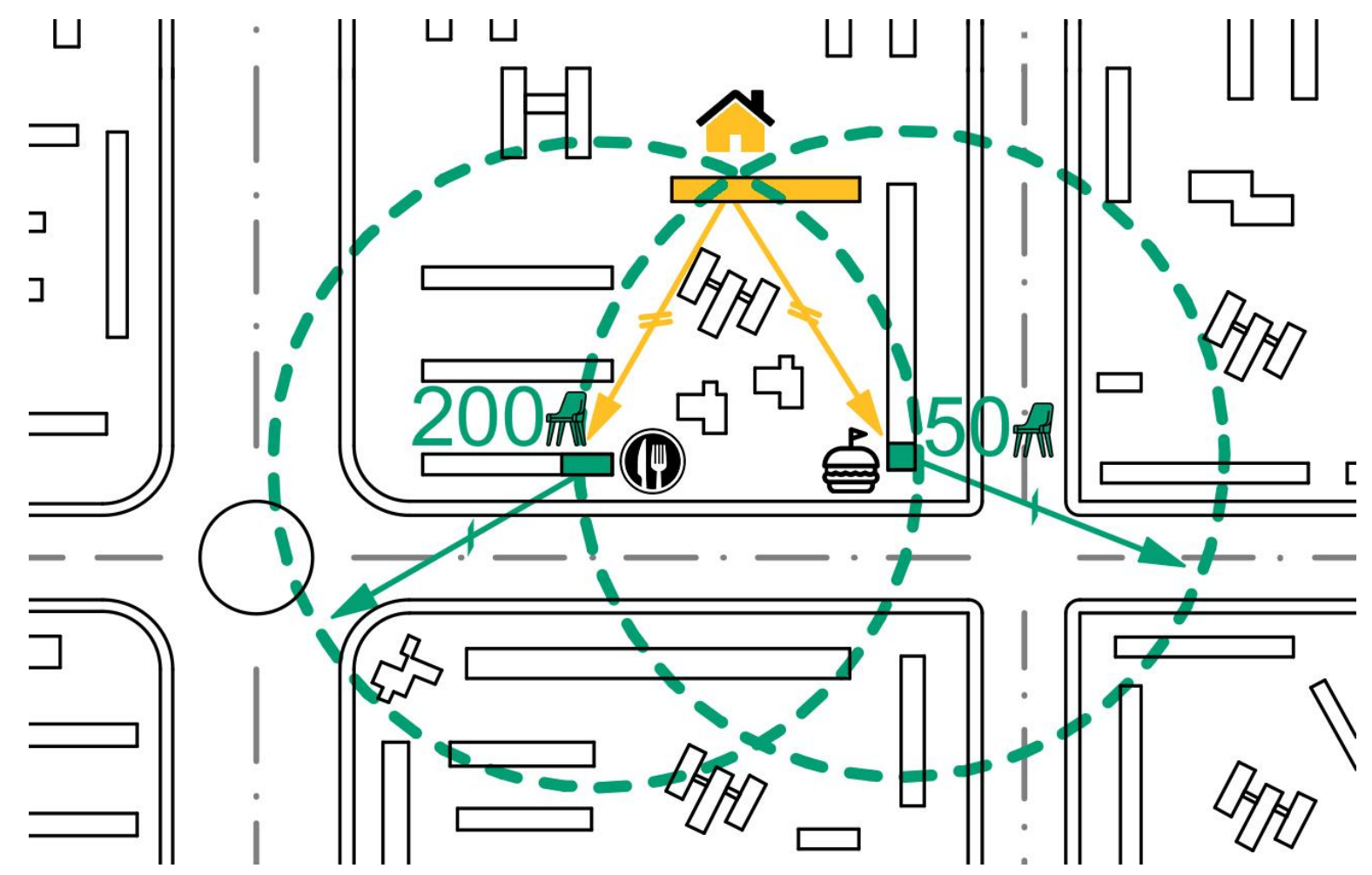

Fig. 5. The diagram shows the same distances from home (house icon) to a restaurant with the capacity of 200 seats (restaurant icon), and a fast food facility with the capacity of 50 seats(burger icon), both of which have the same service radiuses. Source: Author.

Instead, criteria such as the leisure of the catering establishment, its exotic nature, its exotic location, fast service, the availability of a variety of cuisines, main walking directions - have a significant impact on the choice of catering establishment by the consumer. Therefore, they must be taken into account when calculating the radii of accessibility to catering establishments.

In the absence of all these criteria except for fast service, such a catering establishment should be considered fast food, the estimated radius of which is 300-500 meters, but this range of radiuses is conditional. Because when assessing the location of the institution in a residential area, such catering establishments are increasingly aimed at delivering food to the consumer in a period of up to 20 minutes, and personal service in them takes 3-5 minutes (UBR). In this regard, it is clear that fast food will not be located in a residential area on such small radii, especially in the unsaturated streets of the residential area. They are located in places of strong footpaths and having 20-minute 
delivery - transport accessibility to the consumer. The consumer will be especially clear in the estimation of time in case of two situations of choice - visiting the institution on foot or ordering delivery. Therefore, the conditional 300-500 meters for fast food are responsible for walking distance for residents near it, and 20-minute delivery - for transport accessibility, which in any case exceeds the maximum radius of service in the residential area -1500 meters. In addition, the fast food network in the case of delivery has not radiuses, but service areas. For the economically active population, this range of radii is $366-611$ meters.

Considering the radiuses plotted on the general plan of the residential area in the form of rings, it is seen that for most entrances of houses, the walking path to the catering establishment will exceed the value of the radius of service of this catering establishment. This situation arises because residents on the periphery of the radius of the catering establishment can not always go directly through the housing to the catering establishment, as well as due to the presence of pedestrian crossings. Most of the routes from the entrances to the houses to the catering establishment will have a winding path (Fig. 6). Therefore, the service radius is rather a service area that does not have the form of a ring, and its boundaries depend on the shortest walking distance to the catering establishment in the center of the zone, rather than an equal circle (Fig. 6). Hypothetically, it can be assumed that the service radii on the master plan had such a shape due to the relative ease of their application to the drawings by hand. But at a time when all drawings are done on a computer, not on paper - it is much easier to make more accurate calculations using at the sketch stage of the project of housing development radiuses of accessibility, and at the next, final stages of design to change such inaccurate radiuses to zones (Fig. 6).

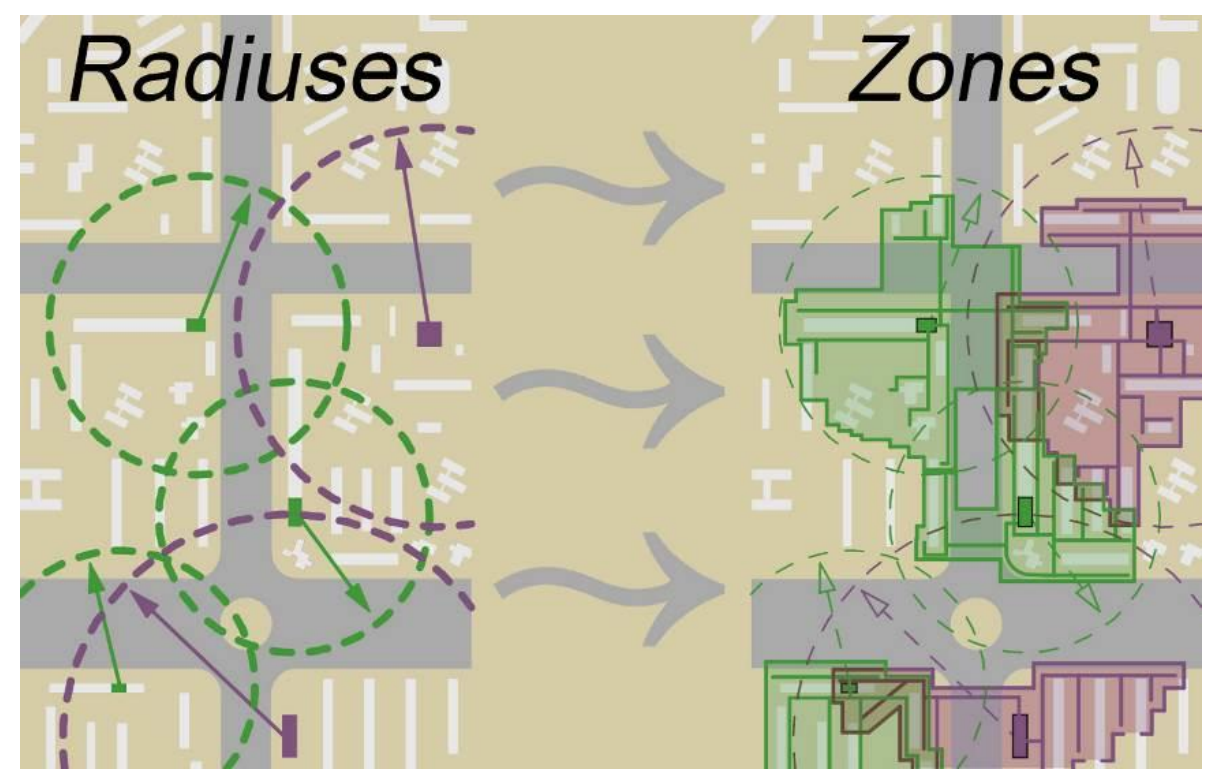

Fig. 6. The difference between accessibility radiuses and accessibility zones. Source: Author

The above-mentioned criterion - the variety of cuisines in a catering establishment is too difficult to provide pedestrian access to all residential buildings in the area, even if it is a leisure catering establishment and not a fast catering establishment. This criterion should primarily be provided by fast delivery areas.

Given the above, we will determine the service radius for all other catering establishments using the above criteria - leisure in the catering establishment, the exotic nature of the catering establishment, the exotic location of the catering establishment, the average walking speed of the economically active population.

$$
\boldsymbol{R}=500 \mathrm{~m}+\left(500 \mathrm{~m}^{*} \mathrm{le}\right)+\left(500 \mathrm{~m}^{*} \text { exo }\right)+\left(500 \mathrm{~m}^{*} \text { exI }\right) \leq 1500 \mathrm{~m}
$$


Where $\mathbf{R}$ - is the service radius for a catering establishment with a walking speed in the current state-building norms of Ukraine (4 kph), meters;

$500 m$ - service radius for catering establishments specified in the current building regulations, meters;

le - the coefficient of leisure of the catering establishment;

exo - the coefficient of exoticism of the catering establishment;

exI - the coefficient of the exotic location of the catering establishment;

$1500 \mathrm{~m}$ - the maximum radius of accessibility in a residential area, according to current building codes, meters.

The coefficient of leisure le: 0 - the catering establishment does not provide leisure; 0.5 - catering facility promotes long-term stay in it, focused on meeting the need for leisure, occasionally provides additional leisure; 1 - the catering establishment promotes long-term stay in it, is completely focused on the satisfaction of need for leisure, and has its additional organization (Fig. 7).

The coefficient of exoticism exo: 0 - the catering establishment is not exotic; 0.25 - a type of catering establishment that has recently appeared, or was new in typology or the method of service, but today this type in the city can be considered common; 0.5 - the catering establishment is new in typology, or method of service, or has recently appeared in residential area (Fig. 8).

the coefficient of the exotic location exl: 0 - the location of the catering establishment is typical; 0.25 - the catering establishment is located unusually in comparison with typical; 0.5 - the catering establishment is located in special species points (Fig. 9)

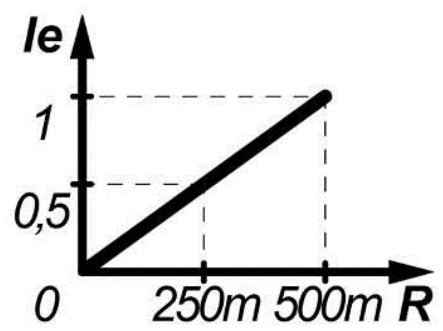

Fig. 7. Influence of leisure coefficient on distance. Source: Author

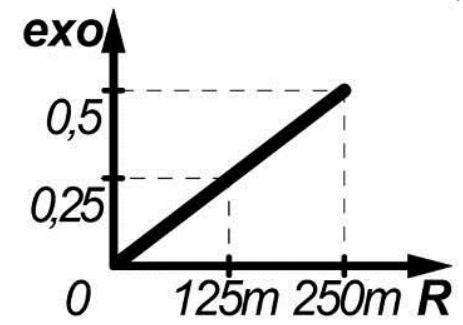

Fig. 8. Influence of the exotic coefficient of a public catering establishment on distance. Source: Author

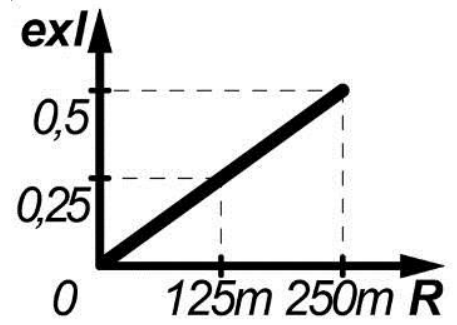

Fig. 9. The influence of the coefficient of exotic location of the catering establishment on the distance. Source: Author

Since in the section "Influence of walking speed" we determined that the average walking speed of the economically active population is $4.89 \mathrm{kph}$, which is $122.2 \%$ more than the average walking speed in the regulations, then a more accurate radius of catering for the economically active population will be calculated by the formula.

$$
\boldsymbol{R}_{e a}=\boldsymbol{R}^{\star} 122,2 \%
$$

$\boldsymbol{R}_{e a}$ - service radius for a catering establishment taking into account the average walking speed of the economically active population, meters;

$\boldsymbol{R}$ - service radius for catering establishments with walking speed in the current state-building norms of Ukraine (4 kph), meters;

$122,2 \%$ - the coefficient of increase of the standard walking speed to the average speed of the economically active population (4.89 kph), percent. 


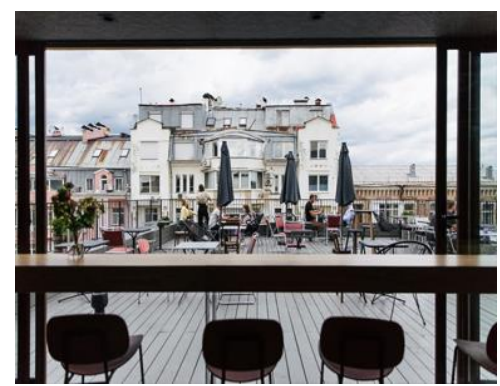

Fig. 10. Rooftop bar "1818". Source: (The village)

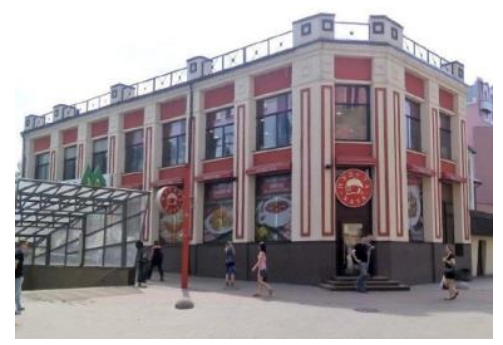

Fig. 11. Fast restaurant "Puzata khata" Source: Fot. author

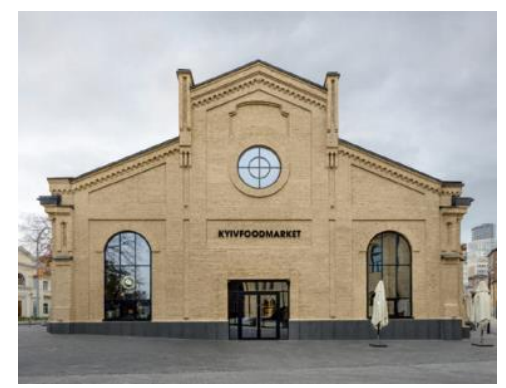

Fig. 12. New "Kyiv Food Market" Source: (Hospitalitysnapshots)

For example, we will find a service radius for a new rooftop bar "1818" in a residential building in the Podil district, Kyiv (The village)(Fig. 10). We will first determine the coefficients. This bar is a leisure catering establishment as it provides a range of alcoholic beverages, the price is above average, the waiter service is available, but the establishment does not organize additional leisure. Therefore, the coefficient of leisure le for this catering establishment $-0,5$. The bar is exotic because it has recently appeared and is of interest to consumers, respectively, the coefficient of exoticism exo-0,5. The location of the bar will be estimated by the highest coefficient of the exotic location exI-0,5, as it is located in a residential building on the roof of the Bursa hotel complex, and has an interesting viewpoint overlooking the residential area and architectural monuments.

So, the calculation of the service radius of the bar "1818" in residential buildings will look like this:

$$
\begin{gathered}
\boldsymbol{R}_{(\mathrm{bar})}=500 \mathrm{~m}+\left(500 \mathrm{~m}^{*} 0,5\right)+\left(500 \mathrm{~m}^{*} 0,5\right)+\left(500 \mathrm{~m}^{*} 0,5\right) \leq 1500 \mathrm{~m} \\
\boldsymbol{R}_{(\mathrm{bar})}=1250 \mathrm{~m} \leq 1500 \mathrm{~m} \\
\boldsymbol{R}_{\text {ea }(\mathrm{bar})}=1250 \mathrm{~m}^{*} 122,2 \%=1528 \mathrm{~m}
\end{gathered}
$$

As a result, we have a service radius of 1,528 meters for purposeful visits to this catering establishment.

In comparison, we will make the calculation for a public catering establishment of a network of the Ukrainian fast restaurants "Puzata khata" which is located nearby (Fig. 11). This establishment does not provide leisure, is not exotic, and is not exotically located, respectively, all the coefficients will be zero. Therefore, the calculation of the radius will look like this:

$$
\begin{gathered}
\boldsymbol{R}_{\text {(fast restourant) })}=500 \mathrm{~m}+\left(500 \mathrm{~m}^{*} \mathrm{0}\right)+\left(500 \mathrm{~m}^{*} 0\right)+\left(500 \mathrm{~m}^{*} \mathrm{O}\right) \leq 1500 \mathrm{~m} \\
\boldsymbol{R}_{\text {(fast restaurant })}=500 \mathrm{~m} \leq 1500 \mathrm{~m} \\
\boldsymbol{R}_{\text {ea }(\text { fast restaurant })}=500 \mathrm{~m}^{*} 122,2 \%=611 \mathrm{~m}
\end{gathered}
$$

So, we get a service radius of 611 meters for a purposeful visit to this catering establishment.

A new type of catering establishment for Ukrainian cities - a food market (Hospitalitysnapshots) can reach the maximum radius of purposeful pedestrian accessibility (Fig. 12). At the maximum values of all coefficients, the radius of pedestrian accessibility of the economically active population to it will be 1,833 meters.

Changes in the service radiuses of catering establishments depending on the slope of the area should be taken in accordance with Annex E.6 (DBN B.2.2-12:2019, 2019, p. 159).

To place catering establishments in the existing residential area and to provide its residential buildings with pedestrian accessibility to different types of public catering establishments, we have developed the following algorithm of actions. 
The preparatory stage of placement:

- Calculate the number of seats needed by the population of the residential area (Lytvynenko S. 2009. p. 1).

- Conduct a field survey of existing catering establishments to determine their capacity and provide each type of establishment with coefficients of leisure, the exoticism of establishments, and the exoticism of the location.

- Determine the shortage of catering establishments by type and number of seats.

- Calculate the radii of service of existing catering establishments and plot them on the plan of the residential area, as a result, we will identify places of non-provision or insufficient provision of residential buildings with types of public catering establishments and pedestrian accessibility to them.

- Identify the main pedestrian directions in the residential area.

- Determine the needs of the population in the types of catering establishments and their targeted ratio by capacity using the method of citizen participation (Pérez-delHoyo R. 2018. p. 206-213).

The final placement stage:

- Receive an order to design and place the required type of catering establishment from the customer.

- Based on the customer's survey, specify the type of catering establishment, its capacity, price segment, and approximate coefficients of leisure, exoticism, and exoticism of accommodation.

- Calculate the service radius of the catering establishment that is being designed.

- Use capacity, the radius of service, and main pedestrian directions to determine the possible location of a catering establishment in a residential area, which will provide the majority of insufficiently provided residential buildings with types of catering establishments and pedestrian accessibility to them.

- Check the accessibility of the catering establishment that is designed by changing the radii to service areas and specify the possible locations.

- Offer the customer possible places for placing catering facilities and agree on them.

Thus, using this algorithm, the architect will be able to influence the location of catering establishments according to the system, which will ensure even distribution of public catering establishments in the residential area and provide pedestrian accessibility to various types of public catering establishments to preserve the free time of the population and to release the transport load of the city.

\section{MATERIALS AND METHODS}

To make this study we conducted an analysis of other researches and standards for the location and typology of catering establishments, based on which we formulated the definition of catering establishments, the placement of which is discussed in the article.

The method of abstraction is used to determine new radii of accessibility to food establishments (rsatu). Thus, catering establishments are located in ideal weather conditions, in a residential area without landscape slopes, winter and summer periods are not taken into account, and changes in catering establishments according to seasons, tourist seasons, epidemics. Catering establishments, provide the same set of dishes for their type. In this study, catering establishments do not have specific working hours, but due to their location in residential buildings, establishments should be closed at a time when they should not disturb the comfort of residents. This time is different for each country and even city.

With a service radius of $500 \mathrm{~m}$ and 15 minutes of walking distance, we confirmed that the estimated speed of people in building codes is $4 \mathrm{kph}$, which confirms the study Yaremenko L. (Yaremenko L., 2004, p 156). Using a study by Schimpl M, et al. we found that the walking speed of the economically active population is $122.2 \%$ higher than that specified in the building codes. 
Thus, we know the value by which to increase further calculations of service radii that are made based on the distances specified in the building codes.

The method of assessing the provision of the population in urban planning practice is the division of the population into socio-demographic groups for calculations and research personally for these groups, for example, research Yaremenko L. (Yaremenko L., 2004, p 156). But in our study, such a division into social groups is partially absent. We only considered the population according to age and average walking speed. All calculations of our study were conducted for the so-called economically active population of Ukraine because, by order of the Minister of Economy of Ukraine, the calculation of public provision of catering establishments should take into account only the economically active population, which for Ukraine is 15-70 years. (Lytvynenko S., 2009, p. 1). It should be noted that this calculation has not yet been taken into account by any researcher of the system of accommodation of public catering establishments in residential development.

The study considers only targeted visits to catering establishments in a residential area, to meet the need for food, food and leisure, or mainly leisure. Thus, accidental visits to this institution by a consumer who is on a walk, not at work or at home - is not taken into account. In this regard, we considered two situations of targeted consumer visits to catering establishments, based on which we confirmed the hypothesis of the need for different service radii for fast food and leisure types of catering establishments.

Also in the research, the method of formalization is used, in the creation of the abstractmathematical model revealing the essence of the processes studied in reality (rsatu). Thus, using the analysis of the literature and state building codes, the author determined the range of radius with a minimum value of 300 meters and a maximum of 1500 meters.

Next, we found the influence coefficients, for which the author identified and evaluated the criteria that affect or do not affect the availability of catering in residential areas. Accordingly, those criteria that affect the radius of service received three coefficients of influence each.

We have developed a formula $R=500 m+\left(500 m^{*} l e\right)+\left(500 m^{*} e x o\right)+\left(500 m^{*}\right.$ exl $) \leq 1500 m$ whose calculation results are defined as the sum of the normative radius with the products of three coefficients of influence. We determined the final radius of service for the economically active population by multiplying the obtained results by the coefficient of increase of the average walking speed (122.2\%). So, we received an individual service radius for each catering establishment in the residential area. Based on the defined criteria, catering establishments that provide leisure have larger radii of accessibility, which is confirmed by our examples of calculation of three different types of catering establishments.

In the final part, we provided an algorithm for using these calculations to solve the problem of placing catering establishments in a residential area. We divided this algorithm into the preparatory and the final placement stages.

\section{RESEARCH RESULTS}

The results of the study are an update of the system of accommodation in the residential area of catering establishments. We confirmed our hypothesis that existing catering establishments cannot have the same service radii and should be classified into leisure, fast and mixed types. Different types should have their own service radii, which will help to place these catering establishments in a residential area, ensuring more or less even placement and pedestrian accessibility of most types of catering establishments to the consumer in modern conditions of residential areas. The most common catering establishments in the price segments should be provided with walking access. The most common price segments for the city of Kyiv are Fast Food+Fast Casual, Quick Service Restaurant+Quick\&Casual, Casual Dining, Top Casual Dining.

To calculate the service radii of leisure and mixed types of catering establishments, we created the formula $-\boldsymbol{R}=500 m+\left(500 m^{*}\right.$ le $)+\left(500 m^{*}\right.$ exo $)+\left(500 m^{*}\right.$ exI $) \leq 1500 m$ 
According to the formula, the exotic types of catering establishments and the exotic nature of their location can increase the radius of service up to 250 meters each, and the criteria of leisure in public catering establishments can increase the radius of availability up to 500 meters. From the results of radiuses calculations, it follows that the same type of catering establishment may have the same name, but each object of this type of catering establishment will have different radii based on different values of coefficients.

The doubling of the radius of service of leisure catering establishments is confirmed by our analysis of the influence of the presence and absence of leisure on the nature of attendance and walking accessibility. The orientation of the catering establishment to meet the needs of humans in leisure tells us about a purposeful visit to the institution in one direction - from home to catering establishment, which is characteristic of human free time. The lack of satisfaction of the need for leisure tells us about the nature of quick visits to the catering establishment in two directions - from home to the catering establishment and back, which is typical for people's working hours. Thus, having 15 minutes on walking accessibility to public catering establishments, fast catering establishments will be located twice closer to consumers than leisure catering establishments.

Also, during the study, it was determined that the average walking speed of the economically active population is $4.89 \mathrm{kph}$, which is $122.2 \%$ higher than the average walking speed in the calculations of state building codes of Ukraine $-4 \mathrm{kph}$. These data are used in the final calculation of the service radius for the economically active population, namely in the formula which aims to clarify the calculations of service radii of all types of catering establishments $-\boldsymbol{R}_{e a}=\boldsymbol{R}^{\star} 122,2 \%$

Summarizing the results of calculations, fast food establishments are proposed to be located with ranges of service radii from $366 \mathrm{~m}$ to $611 \mathrm{~m}$, depending on the population density in the residential area. Leisure and mixed types of catering establishments are proposed to be placed from $611 \mathrm{~m}$ to 1833 meters depending on the coefficients le, exo, exl. Fast food restaurants tend to organize delivery, the service area of which is usually greater than the distance of the maximum service radius in a residential area.

The author also developed the algorithm of actions for an architect in case of need to provide the residential area with catering establishments. In the algorithm, the calculation of service radii according to the formulas defined by us is at both the preparatory and final stages of placement.

Through the introduction of this algorithm in the practice of urban planning, the architect has an influence on the choice of location, which the architect did not have before, because of the interests of the customer (the owner of the catering establishment). The algorithm of actions for placement should unite the interests of the customer in the profitability of the catering establishment and the interests of the population of the residential area in ensuring pedestrian accessibility to public catering establishments of different types.

The criterion of variety of cuisines in a residential area should primarily be provided by fast delivery areas.

The capacity of catering establishments does not affect the choice of the type of catering establishment by the consumer (Fig. 5), but it has an impact on determining the possible location of the catering establishment at the final stage of placement of the mentioned algorithm of actions.

\section{DISCUSSION}

The need for walking access to catering establishments may change over time. Therefore, we assume that with the further development of the delivery network, the number of fast food establishments in the residential area will decrease. They will either provide leisure or will be transformed into kitchen factories - establishments that organize delivery and catering. Accordingly, the need for pedestrian accessibility to fast food establishments will either remain unmet or with a change in the format of fast food pedestrian accessibility will not be required for both the consumer and the owner of the establishment, which will also reduce the floor-space of public catering establishments. 
We agree with the study of the classification of food establishments by price segments developed by Yurchak E., but it is unknown whether there is a line between those catering establishments that need and don't need walking accessibility (Yurchak E. 2018. p. 83). It can be assumed that establishments of price segments more expensive than Top Casual Dining due to their small ratio should not a priori be within walking accessibility, as they are not every day but sporadic (in the case of weddings, corporate events, etc.). However, the location of such a catering establishment in a residential area should still be in a single system. However, the location of such a catering establishment in a residential area should still be in a single system. Therefore, pedestrian accessibility for catering establishments of higher price segments should be determined by the formula of service radii and placed in a residential area according to the provided algorithm.

There may be a situation where an establishment that can be classified as fast, such as a coffee house, may have an exotic location, and then the service radius of such an establishment according to the formula will be more than 611 meters, then it is not clear whether this establishment should be classified mixed? The same situation with fast food in which leisure can be provided as an exception, according to the formulas defined by the author, the availability of leisure in the catering establishment will double its service radius, but can fast food be classified as a leisure catering establishment, or does it remain a fast catering establishment? But we are confident that regardless of the classification of the catering establishment and its type name, the decisive factor in the location of catering establishments is its service radius calculated according to the presented formulas.

Among the fast catering establishments, in our opinion, food courts located in supermarket chains located in a residential area can really provide walking access to housing (Fig. 1). But since the food court is an additional function to the supermarket, not the main one, we can not influence its placement in a residential area, but when placing new catering establishments, the service radius of the food court in the supermarket or mall should be considered.

Changing the calculated radii to service zones in some places will again reveal a visual lack of accessibility to catering establishments. It turns out that if you use the radius without taking into account the average speed of the economically active population (without multiplying the radius by $122.2 \%$ ), the radius will more accurately correspond to the service area. There raises the question of whether it can be argued that the population of the house is non-provision access to the catering establishment only because it is longer to walk to it for a conditional 1-5 minutes? We believe that no because the primary task of calculating the radii is the uniform placement of catering establishments of different types in the residential area, respectively if this condition is met, the residential area can be considered provided with public catering.

Catering establishments should no longer be located without a system, only at the request of private entrepreneurs. We believe that for the functioning of the catering system in modern realities, our algorithm of actions in the case of its implementation will allow the architect to influence the systematic placement of catering establishments. We believe that the need for types of catering establishments should be determined by the citizen participation of the residential area and the chief architect of the community (Pérez-delHoyo R. 2018. p. 206-213). Thus, it is possible to achieve the coincidence of interests of the population of the residential area and private owners of catering establishments.

The issue of classification of public catering establishments that provide a place to work with a laptop remains unresolved. This format is new and non-standard, so our options for routes of the population during working and leisure time can not be used for these types of catering establishments. It is possible that a catering establishment that provides a place to work should be considered as coworking, but we can consider it as a catering establishment only if its main function is to provide food to the population. Over time, this format of catering establishments should occupy its price segment and determine the rules for providing services to consumers. It is possible that the uniform placement of such institutions in the residential area will give the residential area additional citizen participation due to additional space for communication. 
The exoticism of the establishment over time and the emergence of similar catering establishments will decrease, respectively, its service radius will decrease, to maintain the maximum value of exoticism, the owner can update interior solutions, make innovations in the establishment and menu.

\section{CONCLUSIONS}

As a conclusion, we can hypothesize that with the further development of the delivery network, the number of fast food facilities in the residential area will decrease, and access to them in most cases for remote residential areas will be provided by a network of supermarkets with ready products and a place to eat, like a food court. We also predict an increasing division of catering establishments into fast food facilities and leisure food facilities. This distribution of the typology of catering establishments will directly affect the frequency of their placement.

In further work on the creation of an updated system of public service by catering establishments, the average walking speed of the economically active population is a more accurate calculation parameter. However, in the preparatory and final stages of determining the location of catering establishments in a residential area, service radii should be used without increasing them by the average walking speed of the economically active population, as in this case, the smaller radius is better correlated with the catering service zone. Thus, the coefficient of average walking speed of the economically active population should be used at the final stage of designing a catering establishment to visually check the provision of catering in service zones.

The calculation of the service radius of a catering establishment located in a residential area should be used regardless of its price segment. However, the placement of catering establishments in a residential area can be considered successful if each residential building has access to fast food and leisure establishments in the most affordable price segments, visits to public catering establishments by economically active residents are daily and periodic.

In summary, in the modern realities of urban planning in Ukraine, the architect has no influence on the location of catering establishments in the residential area. The introduction of these developments in the practice of urban planning may change the situation. Ensuring pedestrian accessibility of catering establishments to the consumer requires a lot of preparatory work. We plan to conduct further research to develop the classification of catering establishments. We also plan to identify several algorithms of actions for providing placement catering establishments in new residential areas at the design stage.

\section{BIBLIOGRAPHY}

DBN V.2.2-12:2019 Planuvannia i zabudova terytorii. [Chynni z 1 zhovtnia 2019 r.] Vyd. ofits. Kyiv : Minrehionbud Ukrainy. 2019. p. 185. https://dreamdim.ua/wp-content/uploads/2019/07/DBN-B22-122019.pdf access 2021-07-25

DBN V.2.2-25:2009 Pidpryiemstva kharchuvannia (zaklady restorannoho hospodarstva). [Chynni vid 2010-0901] Vyd. ofits. Kyiv : Minrehionbud Ukrainy. 2010. p. 177. https://www.minregion.gov.ua/wpcontent/uploads/2017/12/71.1.-DBN-V.2.2-252009.-Budinki-i-sporudi.-Pidpriyemstva.pdf access 2021-0725

Dipromisto, http://dipromisto.gov.ua/files/NMD/PT9.pdf access 2021-07-25

DSTU 3862-99. Public Catering. Terms and definitions [Chynnyi vid 2003-12-01]. Vyd. ofits. Kyiv, 2003. p. 26. https://dnaop.com/html/40988/doc-ДСТУ_3862-99 access 2021-07-25

DSTU 4281:2004. Establishments of the catering trade. Classification. [Chynnyi vid 2004-07-01]. Vyd. ofits. Kyiv, 2004. p.18. https://dnaop.com/html/34057/doc-_СТУ_4281_2004 access 2021-07-25

Greatist, https://greatist.com/health/average-walking-speed\#average-speed-by-age access 2021-07-29

Hospitalitysnapshots, https://hospitalitysnapshots.com/projects/8487/kiev-food-market/ access 2021-09-01

Issuqtalbelt, https://issuqtalbelt.com access 2021-08-28 
Kulaga V. et al. System and complexes of cultural and consumer services (method of using specific sociological research). M.: Stroyizdat. 1975. p 86

Lytvynenko S. Procedure for the application of standards for the provision of places in restaurant facilities. Ministry of Economy of Ukraine. 2009. p. 1. https://zakon.rada.gov.ua/laws/show/z1016-09\#Text access 2021-07-25

Nikolaenko V. Methods of architectural forming citywide system of public catering. Poltavskyi natsionalnyi tekhnichnyi universytet imeni Yuriia Kondratiuka. 2013. p. 160. https://nrat.ukrintei.ua/searchdoc/0413U003473/ access 2021-07-25

Pérez-delHoyo R, et. al. Citizen Participation in Urban Planning-Management Processes - Assessing Urban Accessibility in Smart Cities. SMARTGREENS. 2018. p. 206-213. DOI:10.5220/0006704202060213

rsatu, https://www.rsatu.ru/upload/medialibrary/49f/Lektsiya-6.pdf access 2021-07-25

Schimpl M, et al. Association between walking speed and age in healthy, free-living individuals using mobile accelerometry - A cross-sectional study. PLOS ONE. 2011. p. 7. DOI: 10.1371/journal.pone.0023299

The village, https://www.the-village.com.ua/village/food/new-place/273755-kyiv-1818-bursa-podil-cocktails access 2021-07-25

Troshkin A. Foreign food facilities and their location in cities. Teoriia ta praktyka dyzainu: zb. nauk.prats. K.:NAU, Vyp. 22. 2021. pp. 95-106. DOI: 10.18372/2415-8151.22.15398

Troshkin A. Current status of the network of public catering facilities in Kyiv. K.: NAOMA. 2019. pp. 76-82. https://doi.org/10.33838/naoma.28.2019.76-82 access 2021-07-25

UBR, https://ubr.ua/leisure/it-is-interesting/eksperty-skolko-ukrainec-mojet-jdat-bludo-v-restorane-439657 access 2021-07-25

ukrstat, http://www.ukrstat.gov.ua/metod_polog/metod_doc/2011/12/metod.htm access 2021-07-25

Yaremenko L. Planning and improvement of residential areas. K.: Izdatelskiy dom A.S.S. 2004. p 156.

Yurchak E. Brand management of catering establishments networks. Kyiv National University of Trade and Economics 2018. p. 339 https://nrat.ukrintei.ua/searchdoc/0418U001740/ access 2021-09-12

\section{AUTHOR'S NOTE}

Architect, postgraduate student, The National Academy of Fine Arts and Architecture, Department of Theory, History of Architecture and Synthesis of Arts, Kyiv, Voznesensky Descent, 20, 04053. Research interests: The formation of a network of objects of public catering facilities in residential development (on example, the city of Kiev).

Contact | Kontakt: arseniy.troshkin@gmail.com 